\title{
A Pygmy Blue Whale (Cetacea: Balaenopteridae) in the Inshore Waters of New Caledonia ${ }^{1}$
}

\author{
Philippe Borsa ${ }^{2,3}$ and Galice Hoarau ${ }^{4}$
}

\begin{abstract}
The occurrence of a blue whale is reported for the first time for the New Caledonian archipelago. The whale, a juvenile male in poor condition, entered the shallow inshore waters of the coral reef lagoon $\left(22^{\circ} 19-24^{\prime} \mathrm{S}, 166^{\circ}\right.$ $46-52^{\prime} \mathrm{E}$ ) where it spent at least 1 month until it was killed by whaler sharks on 27 January 2002. Live observations, examination of photographic documents, and skull osteology indicated that this was a pygmy blue whale, Balaenoptera musculus brevicauda. Nucleotide sequences of PCR-amplified fragments of its mitochondrial DNA were determined and compared with the few published homologous sequences of North Atlantic blue whales, B. m. musculus, but no obvious differences were apparent.
\end{abstract}

Although blue whales are among the most cosmopolitan marine mammals, sightings of blue whales in the Southwest Pacific are reportedly scarce, and all of these but a single sighting at the equator at about $170^{\circ} \mathrm{E}$ occurred south of $30^{\circ} \mathrm{S}$ in the austral summer (Kato et al. 1995, Reeves et al. 1999). Groups of blue whales were observed in the vicinity of the Solomon Islands in August 1957, but no blue whale has been reported from the Southwest Pacific since then (Reeves et al. 1999). Historical catch records show the geographic segregation of two major concentrations of blue whales in the Southern Hemisphere during the austral summer: one north of the Antarctic convergence mainly between $25^{\circ} \mathrm{E}$ and $80^{\circ} \mathrm{E}$, the other south of the Antarctic convergence mainly between $55^{\circ} \mathrm{E}$ and $90^{\circ} \mathrm{W}$ (Ichihara 1966). The strong correlation of geographical location

\footnotetext{
${ }^{1}$ Manuscript accepted 21 October 2003.

2 Institut de Recherche pour le Développement, Département des Ressources Vivantes, BP A5, 98848 Nouméa cedex, Nouvelle-Calédonie (phone: +687 260741; fax: +687 264326; e-mail: Philippe.Borsa@noumea.ird nc).

${ }^{3}$ Corresponding author.

${ }^{4}$ Department of Marine Biology, Centre for Ecological and Evolutionary Studies, Royal University of Groningen, P.O. Box 14, 9750 AA, Haren, The Netherlands.
}

Pacific Science (2004), vol. 58, no. 4:579-584 (C) 2004 by University of Hawai'i Press All rights reserved with body length measured on sexually mature individuals (from whaling data analyzed by Kato et al. [2000]) indicates two geographically separated populations, now recognized to belong to the pygmy (Balaenoptera musculus brevicauda) and the Antarctic (B. m. intermedia) blue whale subspecies, respectively (Rice 1998). One of the current objectives of the International Whaling Commission (IWC) Scientific Committee is to discriminate the two types. Recent developments have led Kato et al. (2002) to propose the utility of blowhole morphology and relative body shape to distinguish them at sea. Here we document the first recorded occurrence of a blue whale in the tropical Southwest Pacific in the summer. A preliminary, unpublished report on the same occurrence (Garrigue et al. 2003) used the criteria of Kato et al. (2002) to propose that the New Caledonian blue whale was a pygmy blue whale. Here we present a detailed chronological account of the observations made on this individual, we add morphological and osteological clues that confirm its identification as the brevicauda subspecies, and we provide partial nucleotide sequences of its mitochondrial DNA as a contribution to genetic databases on blue whales.

\section{MATERIALS AND METHODS}

The observations reported here were made in Baie-du-Prony, New Caledonia, by one of 
us (P.B.) from RV Alcyon (Université de Nouvelle-Calédonie, Nouméa) on 14 and 15 January 2002 and from RV Alis [Institut de Recherche pour le Développement (IRD)] on 25 January 2002. Other field data were gathered on an opportunistic basis by observers interviewed by P.B.

From the numerous pictures of this whale that were taken between 9 January and 29 January, we selected those with key morphological features that reportedly allow cetologists to distinguish $B . m$. brevicauda, the pygmy blue whale, from $B$. m. intermedia, the other form present in the Southern Hemisphere (Ichihara 1966, Omura et al. 1970, Kato et al. 2000, 2002). Some of the photographs examined by us have been published (Anonymous 2002, Clua 2002, David et al. 2002), including some subsequently communicated to the IWC Scientific Committee (Garrigue et al. 2003). Additional pictures were provided by P. Larue (pers. comm.), or taken from public television video footages, or were our own. The latter have been filed at the library of IRD in Nouméa and can be obtained through the corresponding author.

The whale's body length was estimated by measuring with a rope the distance from tip of snout to end of tail on the floating dead animal (on 29 January). Measurements on baleen plates were made to the nearest centimeter using a ruler. Those on tympanic bullae were made to the nearest millimeter using a Vernier caliper.

For genetic analyses, a ca. $1-\mathrm{cm}^{2}$ piece of sloughed skin (now preserved in alcohol at IRD, Nouméa) was recovered in Rade-Nord $\left(22^{\circ} 20^{\prime} \mathrm{S}, 166^{\circ} 52^{\prime} \mathrm{E}\right)$ on 14 January 2002 by snorkeling in the trail of the whale. Approximately $2 \mathrm{mg}$ of skin tissue was subjected to total genomic DNA extraction according to Hoarau et al. (2002). DNA extracts were subjected to polymerase chain reaction (PCR) amplification of both a fragment of the replication-control region of the mitochondrial DNA and a fragment of the cytochrome $b$ gene. For this, we used primer-pairs $D l p 1.5 /$ Dlp 5 of Baker et al. (1998) and CB1-L/CB2-H of Palumbi et al. (1991) and set the annealing temperatures at 54 and $52^{\circ} \mathrm{C}$, respectively. Nucleotide sequences of the two PCR prod- ucts were obtained in both forward and reverse directions using the BigDye Terminator Cycle sequencing kit (Applied Biosystems, Foster City, California) and the foregoing PCR primers as sequencing primers. The products of the sequencing reaction were run in an ABI PRISM 377 automatic sequencer (Applied Biosystems).

We compared the partial mitochondrial DNA sequences of the New Caledonian blue whale with published, homologous sequences. At the time of writing, the total or partial mitochondrial DNA sequences of only five blue whales were publicly accessible. A search of the nucleotide-sequence database of GenBank (http://www.ncbi.nlm.nih.gov/) returned one total mitochondrial DNA sequence for blue whale (GenBank accession no. NC_001601), actually a North Atlantic female blue whale $\times$ male fin whale hybrid (Árnason and Gullberg 1993), and the partial sequence of the 12S rDNA of a blue whale of unknown origin (GenBank AF320513 [Tebbutt et al. 2000]). Browsing the scientific literature through ISI Web of Science (Institute for Scientific Information, Philadelphia), we found the partial cytochrome $b$ gene sequences ( $120 \mathrm{bp}$ at the $3^{\prime}$ end of the gene) of three more individuals (Kimura et al. 1997) and the sequence of a 298-bp fragment of the $5^{\prime}$ end of the control region of another North Atlantic female blue whale $\times$ male fin whale hybrid ("Caneliñas hybrid" [Bérubé and Aguilar 1998]).

\section{RESULTS}

The first confirmed sighting of a blue whale in New Caledonia was on 29 December 2001 as it was swimming in circles at the northern extremity of Canal-Woodin in the southern lagoon of New Caledonia $\left(22^{\circ} 24^{\prime} \mathrm{S}, 166^{\circ} 46^{\prime}\right.$ $\mathrm{E}$; depth 25-30 m). Subsequently (from 31 December onward), the individual was sighted in the nearshore, shallow (ca. 5-30 m) waters of either Grande-Rade $\left(22^{\circ} 19-21^{\prime}\right.$ S, $166^{\circ}$ $\left.49-50^{\prime} \mathrm{E}\right)$ or Rade-Nord (22 $19-20^{\prime} \mathrm{S}, 166^{\circ}$ $\left.51-52^{\prime} \mathrm{E}\right)$, two sheltered coves located in Baie-du-Prony in the southwestern part of New Caledonia's Grande Terre. Invariably, the whale was seen circling randomly within a 


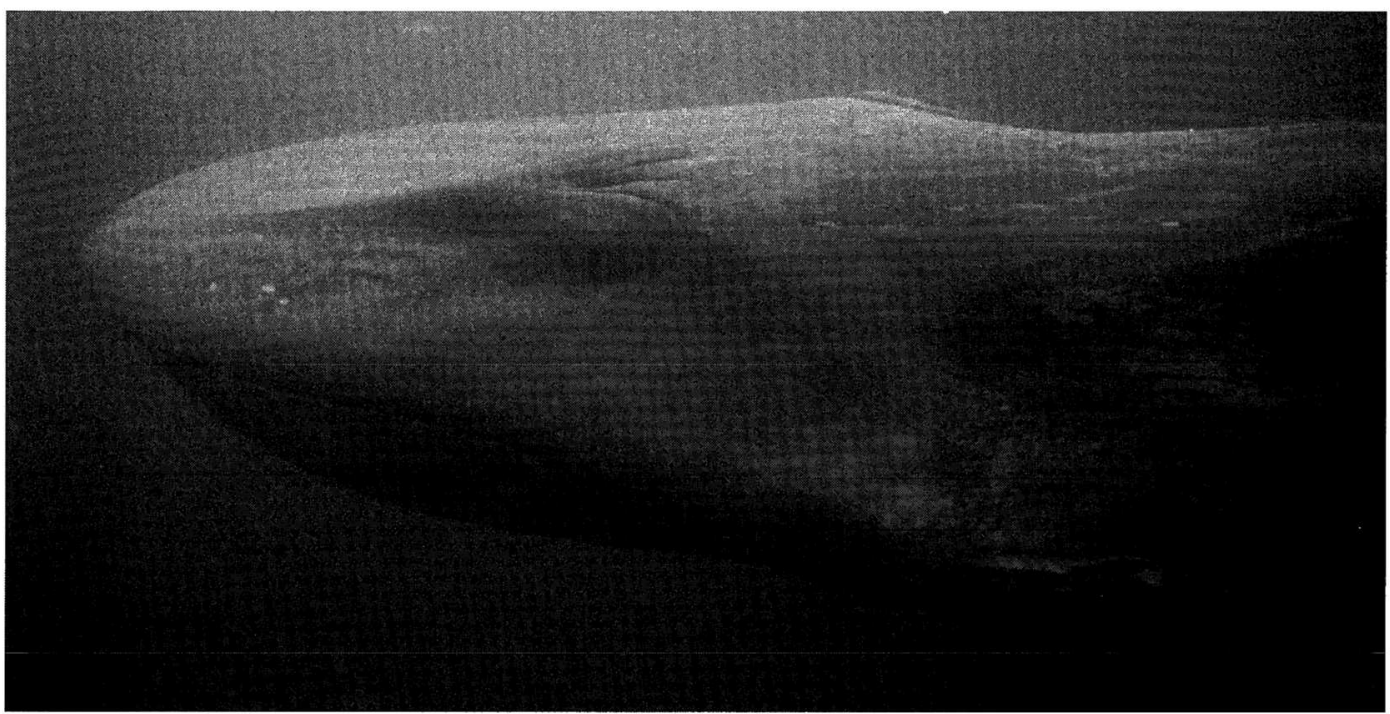

Figure 1. Underwater photograph of the head and neck of the New Caledonian blue whale, Baie-du-Prony, 14 January 2002. (Photograph courtesy of P. Larue.)

radius of a few hundred meters. The whale carried many remoras, Echeneis naucrates, on its head, flippers, flanks, and fluke. There was no evidence that the whale was feeding, and the quantities of potential prey (krill, small pelagic fishes, squids) captured using light traps set on 14 January according to standard protocols (D. Ponton and P.B., unpubl. data) were almost nil in Baie-du-Prony. The whale was emaciated, with prominent jaws, orbital bones, and vertebrae, and a depression in the occipital region, giving it a reptilelike appearance (Figure 1). Stretch marks were visible all along the flanks and tail. All this was suggestive of nutritional stress. The physiological condition of the animal appeared to deteriorate slowly throughout the period it was observed: the average \pm standard deviation dive duration decreased steadily from $138 \pm 44 \sec (n=13$ dives, excluding intervals between blows during a surfacing sequence) on 14 January to $38 \pm 19 \sec (n=8$ dives) on 25 January. Based on a different set of observations, a similar trend was reported by Garrigue et al. (2003). The thin blubber, about $5 \mathrm{~cm}$ thick (later measured on both the ventral and dorsal sides from freshly exposed slices of flesh), confirmed nutritional stress. No external injury was apparent. Early on 27 January in Grande-Rade, the whale was repeatedly bitten by two whaler sharks (identified by us from video footage as either Carcharbinus amboinensis or C. leucas), which were first seen swimming in its vicinity 2 days earlier. Harassment by sharks resumed in the evening, leading to the death of the animal in the night. Surfacing again ca. $36 \mathrm{hr}$ after it sank, the carcass was pulled offshore and left adrift, attracting scavengers including several large tiger sharks, Galeocerdo cuvieri.

The whale's body length was estimated to be $16.5 \mathrm{~m}$. Blue whale calves are weaned at the age of 6-8 months, at which time their size is 16-17 m (Bannister 2002, Sears 2002). Pygmy blue whales reach sexual maturity at a length of ca. $18 \mathrm{~m}$ or more and Antarctic blue whales at a minimum of $22.3 \mathrm{~m}$ (Ichihara 1966). The New Caledonian individual was therefore a juvenile, possibly a newly weaned young-of-the-year. Subsequent examination of the genital area showed that this was a young male.

The live photographs examined by us, including some of those subsequently presented 
in Garrigue et al. (2003), showed the following: (1) anterior tip of the median groove in the blowhole extended beyond the anterior limit of the two nostrils (also visible on Figure 1); (2) proportion of tail length to total length was ca. 0.25 ; (3) the anterior part of the trunk was bulky and the posterior part was thin and elongated. The three foregoing features are more characteristic of pygmy blue whales than of other blue whale subspecies (Ichihara 1966, Kato et al. 2002). The position and relative size of the median groove of the blowhole presumably reflects the shape of the nasal bones, which differs between pygmy blue whales and ordinary blue whales (Omura et al. 1970, Kato et al. 2002). The difference in general body shape is presumably related to the fact that ribs in the anterior portion of the thorax are proportionally longer in pygmy blue whales than in northern blue whales, B. m. musculus (Omura et al. 1970; no data for $B . m$. intermedia). However, one can question whether the shape of the blowhole and the general body shape of the animal are affected by its physiological condition.

The calvarium of the whale, now preserved at Musée de l'Histoire Maritime, Nouméa (MHM), was retrieved from the sea bottom in pieces because several bones were broken and scavengers had chopped out some other chunks. The condition of the skull was characteristic of porotic hyperostosis, in which the outer, dense layer of the bone has disappeared and the porous bone is exposed. Such a pathology is indicative of nutritional stress in humans (van der Merwe 1992). Measurements made on the skull and the baleen plates yielded additional evidence that the New Caledonian blue whale belonged to $B . m$. brevicauda as detailed in the following. The ratio of length to breadth for the six baleen plates preserved at MHM is $1.41 \pm 0.09$ (average \pm SD), a value closer to 1.48 , the average found for $B . m$. brevicauda, than 1.79 , which is the reported average for B. $m$. intermedia (Ichihara 1966). The size of tympanic bullae also differs between blue whale subspecies (Omura et al. 1970). Because this bone ceases to grow early in life (Omura et al. 1970), it can be used independently of body size as a clue for dis- tinguishing pygmy from ordinary blue whales both juvenile and older. The largest length and width of the tympanic bullae (measures no. 1 and 13 of Omura et al. [1970], respectively) in the New Caledonian blue whale were $12.4 \mathrm{~cm}$ and $7.4 \mathrm{~cm}$, respectively. According to Omura et al. (1970), these values tentatively point to the pygmy type $(12.7 \pm$ $1.0 \mathrm{~cm}$ and $6.9 \pm 0.6 \mathrm{~cm}$, respectively) rather than to $B . m$. musculus $(13.5 \pm 1.0 \mathrm{~cm}$ and $7.6 \pm 0.5 \mathrm{~cm}$, respectively) but are excluded from the confidence intervals given for $B . \mathrm{m}$. intermedia (13.7-15.7 $\mathrm{cm}$ and $9.8-11.2 \mathrm{~cm}$, respectively).

Having reached the conclusion that the New Caledonian blue whale specimen was of the pygmy form, we decided to characterize it genetically and add data to the current sequence database of blue whales. The sequence of the control-region fragment of the mitochondrial DNA (now deposited in GenBank under accession no. AY235201) was included between nucleotide sites 15872 and 16375 of the homologous fragment in North Atlantic blue whale (GenBank NC_001601). The two sequences differed by seven transitions, at sites 15975, 15976, 16036, 16105, 16174,16217 , and 16258. Comparing the sequence data with those for the Caneliñas hybrid (298 bp included between sites 15888 and 16185 [Bérubé and Aguilar 1998]) revealed four transitions, at sites 15975, 15976, 16036 , and 16174 . Four of the five mutated sites encountered on the 298-bp fragment between NC_001601 and AY235201 were also variable between AY235201 and the Caneliñas hybrid, but the difference between the Caneliñas hybrid and NC_001601 was three transitions (at sites 16083, 16105, and 16152), one of which (at site 16105) was common with AY235201. The cytochrome- $b$ gene fragment (GenBank AY235202) was included between nucleotide sites 14705 and 15011 of the homologous fragment in North Atlantic blue whale (GenBank NC_001601). The two sequences differed by one transition, at site 14954. No comparison was possible with the sequence data of Kimura et al. (1997) because their and our fragments were chosen at opposite extremities of the cytochrome $b$ gene, with no overlap. Therefore, no obvious 
genetic differences were apparent between the New Caledonian pygmy blue whale (brevicauda type) and two North Atlantic blue whales (musculus type), but to be of some substance such comparisons may have to involve tens if not hundreds of specimens, including some of the intermedia type, and the mitochondrial DNA fragments under comparison probably should be much longer.

\section{DISCUSSION}

Despite decades of intensive hunting that led blue whales to the verge of extinction, knowledge of their geographical structure, population genetics, and migration routes is still fragmentary. Such information is especially desirable in the southern Pacific because it is currently lacking (Reeves et al. 1999) and could be of value in setting up protection policies for this still-endangered species. The fact that before the current observation no blue whale had ever been sighted in the vicinity of the New Caledonian archipelago likely reflects the rarity of this species in the region. The New Caledonian individual was an immature, perhaps a young-ofthe-year. We speculate that it was unable to migrate to its summer feeding ground. A small population of blue whales, perhaps pygmy blue whales, was recently discovered summer-feeding on the upwelling off the southwestern coast of Victoria (Gill 2002). Photoidentification and satellite tracking of those whales may help trace their annual migration route and tell whether it crosses the tropical Southwest Pacific. Given the rarity of blue whale sightings in the Southwest Pacific, a more straightforward test would be to look for the eventual genetic relatedness of the New Caledonian whale with individuals of the southern Australian population (and other populations of the southern Pacific) by comparing their DNA fingerprints.

Recent tests using genetic markers (mitochondrial DNA and microsatellites [Kato et al. (2002), LeDuc et al. (2003); raw data not available though]) on blue whale samples of several tens of individuals from various geographical origins failed to find diagnostic markers of putative pygmy blue whale versus putative intermedia blue whale, thus explaining the lack of obvious genetic differences from the sequence data currently available (this report). Nevertheless, the results announced by Kato et al. (2002) and LeDuc et al. (2003) provide some genetic substantiation to the geographic segregation of pygmy versus intermedia blue whales because those authors reported significant allele frequency differences between them. Thus, it is likely that increasing the number of loci in future genetic tests will increase the ability to separate the two forms. These results, still preliminary, offer exciting perspectives on the evolutionary mechanisms that have led to the presence of two forms of blue whales in the Southern Hemisphere.

\section{ACKNOWLEDGMENTS}

We thank C. Chauvet (Université de Nouvelle-Calédonie, Nouméa), E. Clua (Ministère de l'Agriculture, France), and R. Proner (IRD, Nouméa) for arranging field trips to Baie-du-Prony; E. Clua, J.-Y. Halo, S. Jacquet (IRD, Nouméa), and D. Rames for sharing their observations; L. Frigo (Museum Victoria, Melbourne), C. Garrigue (IRD, Nouméa, then at University of Auckland), and R. G. LeDuc (Southwest Fisheries Science Center, La Jolla [SWFSC]) for email correspondence; and L. T. Ballance (SWFSC) and H. Kato (National Research Institute of Far Seas Fisheries, Shizuoka) for helpful comments.

\section{Literature Cited}

Anonymous. 2002. Un géant des mers à Prony. Nouv. Calédoniennes 9212:1,10.

Árnason, Ú., and A. Gullberg. 1993. Comparison between the complete mtDNA sequences of the blue and the fin whale, two species that can hybridize in nature. J. Mol. Evol. 37:312-322.

Baker, C. S., L. Flórez-González, B. Abernethy, H. C. Rosenbaum, R. W. Slade, J. Capella, and J. L. Bannister. 1998. Mitochondrial DNA variation and maternal gene flow among humpback whales of the 
Southern Hemisphere. Mar. Mamm. Sci. 14:721-737.

Bannister, J. L. 2002. Baleen whales. Pages 62-72 in W. F. Perrin, B. Würsig, and J. G. M. Thewissen, eds. The encyclopedia of marine mammals. Academic Press, San Diego.

Bérubé, M., and A. Aguilar. 1998. A new hybrid between a blue whale, Balaenoptera musculus, and a fin whale, B. pbysalus: Frequency and implications of hybridization. Mar. Mamm. Sci. 14:82-98.

Clua, E. 2002. Présence et mort d'une baleine bleue sur les côtes néo-calédoniennes: Quels enseignements scientifiques en tirer? Bull. Méd. Calédonien Polynésien 28:25-29.

David, J.-L., E. Clua, P. Borsa, P. Larue, and B. Civet. 2002. Va-t-elle mourir à Prony? Nouv. Calédoniennes 9217:1-3.

Garrigue, C., E. Clua, and D. Breitenstein. 2003. Identification of a juvenile pygmy blue whale in New Caledonia, South-West Pacific. Int. Whaling Comm. Pap. SC/55/ SH4 (unpubl.).

Gill, P. C. 2002. A blue whale (Balaenoptera musculus) feeding ground in a southern Australian coastal upwelling zone. J. Cetacean Res. Manage. 4:179-184.

Hoarau, G., A. J. Rinjsdorp, H. W. Van der Weer, W. T. Stam, and J. L. Olsen. 2002. Population structure of plaice (Pleuronectes platessa L.) in northern Europe: Microsatellites revealed large-scale spatial and temporal heterogeneity. Mol. Ecol. 11:1165-1176.

Ichihara, T. 1966. The pygmy blue whale Balaenoptera musculus brevicauda, a new subspecies from the Antarctic. Pages 79113 in K. Norris, ed. Whales, dolphins and porpoises. University of California Press, Berkeley.

Kato, H., T. Miyashita, and H. Shimada. 1995. Segregation of the two sub-species of the blue whale in the Southern Hemisphere. Rep. Int. Whaling Comm. 45:273283.

Kato, H., H. Okamura, A. Nomura, and E. Kojima. 2000. Body length distribution and sexual maturity of southern blue whale, with special reference to sub-species separation. Int. Whaling Comm. Pap. SC/ 52/OS4 (unpubl.).

Kato, H., Y. Honno, H. Yoshida, E. Kojima, A. Nomura, and H. Okamura. 2002. Further developments on morphological and behavioural key for sub-species discrimination of Southerm blue whales. Int. Whaling Comm. Pap. SC/54/LA8 (unpubl.).

Kimura, T., T. Ozawa, and L. A. Pastene. 1997. Sample preparation and analysis of mitochondrial DNA from whale baleen plates. Mar. Mamm. Sci. 13:495-498.

LeDuc, R. G., A. E. Dizon, M. Goto, L. A. Pastene, and R. L. Brownell, Jr. 2003. Patterns of genetic variation in southern hemisphere blue whales. Int. Whaling Comm. Pap. SC/55/SH9 (unpubl.).

Omura, H., T. Ichihara, and T. Kasuya. 1970. Osteology of pygmy blue whale with additional information on external and other characteristics. Sci. Rep. Whales Res. Inst. Tokyo 22:1-27.

Palumbi, S., A. Martin, S. Romano, W. O. McMillan, L. Stice, and G. Grabowski. 1991. The simple fool's guide to PCR, v. 2.0. University of Hawai' i, Honolulu.

Reeves, R. R., S. Leatherwood, G. S. Stone, and L. G. Eldredge. 1999. Marine mammals in the area served by the South $\mathrm{Pa}$ cific Regional Environment Programme (SPREP). SPREP, Apia.

Rice, D. W. 1998. Marine mammals of the world: Systematics and distribution. Soc. Mar. Mamm. Spec. Publ. 4:1-231.

Sears, R. 2002. Blue whale. Pages 112-116 in W. F. Perrin, B. Würsig, and J. G. M. Thewissen, eds. The encyclopedia of marine mammals. Academic Press, San Diego.

Tebbutt, S. J., R. E. Stewart, and D. F. Hill. 2000. Isolation and characterisation of DNA from whale bone. J. R. Soc. N. Z. 30:365-371.

van der Merwe, N. J. 1992. Reconstructing prehistoric diet. Pages 369-372 in S. Jones, R. D. Martin, and D. R. Pilbeam, eds. The Cambridge encyclopedia of human evolution. Cambridge University Press, Cambridge. 